Article

\title{
Conserving Biocultural Diversity through Community-Government Interaction: A Practice-Based Approach in a Brazilian Extractive Reserve
}

\author{
Marjolein L.J. Mooij *, Sabina Dessartre Mendonça and Koen Arts@ \\ Forest and Nature Conservation Policy Group, Wageningen University and Research, \\ 6708 PB Wageningen, The Netherlands; dmsabinadocs@gmail.com (S.D.M.); koen.arts@wur.nl (K.A.) \\ * Correspondence: marjolein.mooij@wur.nl
}

Received: 24 September 2018; Accepted: 18 December 2018; Published: 21 December 2018

\begin{abstract}
We examined how community-government interaction may promote or hinder the conservation of biocultural diversity. Research was done with the extractive community of the Reserva Extrativista Riozinho da Liberdade, located in the state of Acre, Brazil. The reserve is governed by ICMBio, a Brazilian governmental organisation overseeing reserve policy implementation. This paper describes the interaction between ICMBio and the inhabitants of Riozinho da Liberdade. A Practice-Based Approach was used as a theoretical scope to look at the interaction on a practical level. It was found that ICMBio tried to develop the living standards of community members in various ways, for example, by offering suggestions for the improvement of livelihoods, and by proposing alternatives for consumptive behaviour. Although the relationship between ICMBio and the community was generally valued by community members, this did not always equal compliance with ICMBio's rules, or responsiveness to ICBMIO's suggestions for development. Our results show that although compliance was often suboptimal from a government perspective, biocultural diversity may still be reproduced through close interaction between community and government, and thus conserved. As such, our investigation provides counterweight to the abundant empirical evidence on the harmful social consequences of government interference in local nature governance. A main methodological insight of our work is that a Practice-Based Approach enabled us to detect (non-)compliant behaviour that would have otherwise likely gone unnoticed.
\end{abstract}

Keywords: community-based conservation; (non-)compliance; extractivism; governmentality; human development; local communities; Reserva Extrativista Riozinho da Liberdade

\section{Introduction}

It is often argued that community practices and traditional ecological knowledge should serve as a starting point for biodiversity conservation [1-3]. This aligns with the notion of community-based natural resource management (CBNRM), which, despite severe criticism, has gained traction in recent decades [4,5]. This notion aims to take communities' lifestyles and wishes as a starting point, and promotes the local forming of institutions (networks, assemblages, agreements, etc.) for sustainable natural resource management [6-8]. Top-down government interventions are generally incompatible with such situations $[9,10]$. Instead, a form of governance is envisioned in which the government and community interact on par [11]. Still, the ultimate goal of such interactions is often constituted by external ideas of environmental sustainability and conservation of biodiversity, and frequently underpinned by financial aid endowed by governments and international NGOs $[12,13]$. CBNRM arrangements can thus conceal friction in worldviews, goals, and motives which may not be directly 
visible from formal agreements between government and community [14]. Instead, these frictions may be voiced through daily actions, local practices, and everyday forms of non-compliance with rules regarding the environment [15]. Importantly, it is through these day-to-day actions that biocultural diversity is often expressed [16]. A Practice-Based Approach (PBA) is suitable to analyse such expressions. A PBA states that in order to examine and possibly improve interactions, one should not just look at agreements, policies and programmes, but also at basic practices relating to the local environment $[17,18]$. This way, a more complete picture of human-nature interaction arises, and a better understanding of the efficacy and acceptance of conservation interventions.

Research has shown that cultural diversity and biodiversity are often related, and conservation of both may go hand in hand [19]. The term for the combination of the two-biocultural diversity [20,21] — focuses on local (sometimes indigenous) practices and values that are related to resource use $[19,22]$. Our overarching theoretical approach to biocultural diversity is that of social constructivism, which emphasises the constituting role of social interaction in shaping the understandings of reality (rather than merely reflecting reality, as often posed by positivist approaches) [23]. A social constructivist engagement of the concept of biocultural diversity thus allows for a holistic approach to the natural environment. It is sensitive to the ways in which social spheres shape various social realities (diversity in languages, knowledge systems, etc.), as well as influence biophysical spheres, and the other way around. It is therefore not surprising that 'biocultural diversity' is frequently linked to the concept of social-ecological systems [21,24], and that it emphasises the adaptive character of such interactions embedded in social-ecological systems [25-27].

It is important to bear in mind that the concept of biocultural diversity has been employed differently in various domains [28], and that it tends to bring together both normative and descriptive elements [29]. With regards to normative elements, the point is that specific types of governance are needed to recognise diversity, and to allow for politicised contextualisation of knowledge and worldviews $[26,30]$. Such values of diversity and realities of bio-cultural interactions may be imperilled once again in Brazil's current political climate [31]. It has been noted though that 'biocultural diversity' itself may become problematic when it is repeatedly linked to 'primitive' ecological knowledge and 'traditional' dimensions of local communities [32]. In the light of a globalizing world in which, e.g., digital networks connect citizens around the world, local communities may see their outlook and constitution changing, as well as their interactions with governmental organisations [32-34].

Interactions between the government and local communities in the context of local nature conservation practices have been described elaborately [11,35-38]. Scholars have also examined consequences for biocultural diversity of particular interactions between communities and competent authorities or legislative frameworks [39-41]. However, explicit examinations of the effects of community-government interaction on the conservation of biocultural diversity are scarce (cf. [25,42]). Moreover, empirical evidence on the interactions between governments and communities generally points at problematic relationships, for which communities tend to bear the costs $[32,35,38]$.

In this paper, we specifically examine the implications of community-government interactions in the context of biocultural diversity conservation. Our results will show that, despite various complications, such interactions do not necessarily have a negative impact on the latter. Our case study is of a local community in the Brazilian Amazon. The community lives in an extractive reserve (Reserva Extrativista Riozinho da Liberdade in Acre state) established by the governmental organisation Instituto Chico Mendes de Conservação da Biodiversidade (ICMBio hereafter). ICMBio is the competent authority governing the reserve.

As the main research question we ask "how community-government interaction on a practical level may promote or hinder the conservation of biocultural diversity". As sub-research questions, we pose the following:

- What expectations towards ICMBio become visible from the daily lives of community members?

- How does ICMBio approach the community, and how are rules and regulations enforced and (re-)produced between local ICMBio staff and community members? 
- How does the community respond to ICMBio's approaches?

\section{Theoretical Background}

At face value, Foucault's development of the notion of governmentality-i.e., "the conduct of conduct" [12] (p. 502) [43] seems an obvious analytical tool for assessing the relationship between ICMBio and the community of the Riozinho da Liberdade. By describing more subtle, inconspicuous, 'microphysical' forms of power, Foucault criticises 'traditional' power conceptions in which power is merely authority-induced, punishment-driven, top-down ruling. Foucault observes that to possess power is not the same as possessing the art of being able to govern successfully [43]. He asserts that an effective governor does not need an instrument to punish its subjects but instead, he can use wisdom and patience [43]. This relates to governmentality, which Foucault further defines as the collection of everything that is relevant for governing successfully: the institutions, analyses, procedures and tactics $[11,12,43]$. Foucault argues that effective ways of governing could partly lie in influencing the agency of ruled subjects, and to create change from within subjects themselves, instead of enforcing rules upon them [44]. The theory holds that it is possible to (implicitly) convince subjects to reject their own ideas and to replace them with others [11,43]. Scholars have developed these ideas extensively [11,45], but certainly in the context of local communities, key weaknesses remain, including: a) the assumption that governing bodies believe that they know what is best for their subjects; $b$ ) that governing bodies automatically assume it is possible to replace subjects' internal ideas and logics [12]; and c) that the agency of subjects can rather easily be overturned or guided [17] (see also the concept of constitutionality [46-48]).

In initial interaction with local ICMBio staff, we did not recognise environmentality as a key way through which ICMBio approaches local communities. We consequently looked for a more befitting conceptual lens to understand the interaction between government and community. Taking into account the need for a more applied method of understanding local practices and governance, Arts et al. [17] further developed the PBA [49,50]. It takes practice as a starting point, and as such, differs from governmentality theories in which local practices and agency tend to be engaged with as an analytical aftermath $[43,44]$. The PBA states that practices, not social interactions, are the foundation of actions. These practices are produced and reproduced through returning daily actions [51,52]. Scholars that laid the foundation for developing the PBA state that to gain advanced insight, it is important to not assume that behaviour is always based on rationality $[43,45,46,48,50-53]$. Rather, behaviour is the complex result of rational thinking, as well as non-deliberate repetition of practical action [52]. Contradicting governmentality, the PBA states that subjects are therefore not able to simply reject their own ideas and replace them with external ideas prescribed by government institutions [51,52]. Practices are shaped over years in close interaction with the environment and with peers, and are often created without the active 'rationalisation' of all their aspects [51,52]. A PBA would contend that, in the context of community livelihoods, biodiversity and biocultural conservation interventions (and their local responses) may be better understood when focussing on local activities, instead of analysing externally directed policies and programmes $[17,54]$.

Empirical evidence has shown the fruitfulness and importance of the PBA [52,55]. Ayana et al. [18] uncovered how the institutional arrangement of an NGO did not match the practices of traditional people, which made the intervention programme destined to fail on the basis of its own intentions. Stellmacher and Mollinga [56] arrive at a similar conclusion after studying local forest management in Kenya. Here, the government tried to reshape forest user groups, without paying much attention to the already existing social structures. This approach turned out to be painfully unsuccessful [56].

The Practice-Based Approach comprises three sensitising concepts: logic of practice, situated agency and performativity [17,51,52]. Logic of practice describes how people do not always actively overthink their actions, rather, they tend to behave according to what they are used to, and what their practices have been over the years, without thinking a lot about the 'why' of their behaviour [57]. Situated agency describes how actors' actions are influenced by their surrounding 
environment $[17,52]$. 'Environment' here refers to all physical and non-physical factors that embed a community, e.g., the location and ecology of the reserve, natural factors that community members are dependent on, participation in digital social media, and interaction between community members [18]. The PBA asserts that it is therefore usually not possible to predict people's actions theoretically, because every action is based on actors' specific agencies relating to their environments. This does not mean that practices remain the same, on the contrary: everyday practices require a certain amount of improvisation, because external factors change continuously [51]. Performativity revolves around how discourses shape actions [52,54]. The way in which actors speak and act upon things, influences practices (and vice versa), regardless of whether these discourses have been 'objectively' constructed, or whether they are scientifically accurate. Such discourses need to be considered in the socio-environmental context in which they have emerged, and according to the PBA, they are a key component underpinning practices [17,50,52].

In this study, we build on the premises and insights of the PBA when studying the interaction between the governmental organisation and our community of focus. It means that rather than studying governance through the consequences of intentions or words on paper, such as ICMBio's management plans, we initiate our analysis from the actual daily actions that feed into the dynamic relationships between government staff and local people.

\section{Materials and Methods}

\subsection{Case Description}

The Amazon rainforest is a prototypical example of a landscape that is inhabited by numerous different indigenous tribes and ethnic groups. Continued pressures from illegal logging, clear-cutting of pastures for cattle farming and agriculture, and illegal extraction of forest products threaten the rainforest and its inhabitants [58-60]. An example of these inhabitants are former rubber tappers. In the state of Acre in western Brazil, communities revolving around the rubber industry resettled close to rivers after the most recent collapse of the rubber market in 1945 and the suspension of price supports that followed. They have since developed their lives around the water [61]. The Instituto Brasileiro do Meio Ambiente e dos Recursos Naturais Renováveis (IBAMA hereafter) was established by the Brazilian government in 1989 to govern these and other traditional communities. The institute primarily did so through the creation of protected areas in Brazil. In 2007, responsibilities over these protected areas were transferred to the then newly established Brazilian governmental organisation Instituto Chico Mendes de Conservação da Biodiversidade (ICMBio hereafter). Today, ICMBio is a governmental organisation within the Ministry of Environment, specialised in protecting and overseeing biodiversity and cultural diversity in Brazil [62]. One of their most important actions continues to be the creation of protected areas-for example, extractive reserves [63]. In extractive reserves, traditional communities can sustain hunter-gatherer livelihoods whilst being protected from external threats such as (illegal) logging activities or cattle ranching. Extractive reserves often represent a wealth of biocultural diversity [64]. The way in which ICMBio interacts with the communities living in these extractive reserves likely influences the type of natural resource management that is concertedly conducted. Research has been carried out on the compliance of local communities with conservation-focussed authorities $[9,58]$, but understanding of processes of compliance and non-compliance, and of the co-creation of rules and regulations between communities and authorities can and needs to be deepened. Such deeper understanding is particularly important in the context of the conservation of biocultural diversity, in which the relationships between communities and authorities is often problematic [4]. Our focus on the traditional community living in the Reserva Extrativista Riozinho da Liberdade followed from a preliminary informal enquiry, suggesting closer interaction between ICMBio's local staff and the community compared to nearby ICMBio reserves. 


\subsection{Data Collection}

A variety of methods was used to obtain field data, including participant observation and formal and informal interviews. Participant observation has proven to be an efficient technique in ethnoecological types of research $[65,66]$. Members of the community were joined in their daily activities to gain information about their lifestyle. As described by Kohn [67], it is extremely hard to describe a non-Western world through a Western perspective. Therefore, and from a PBA at least, participating in the daily lives of people is vital to gain insight into peoples' motives and actions [68]. Bernard (2011) and Albuquerque et al. (2014) confirm this in their texts on anthropological field work [69,70]. Bernard describes how participant observers are able to collect more and qualitatively better data: participants are more involved with the community, and participatory research may reduce the chances of reactivity (informants changing their behaviour when they know they are being studied) [69]. Albuquerque et al. add that community members are more inclined to express themselves spontaneously when participant observation is used, and describe how participant observation can be used as a means for triangulation $[68,70]$. During our study, community members were encouraged to speak their minds freely and we aimed to engage without interfering in their daily lives.

Data was collected over a period of three months (1-11-2017 to 31-01-2018). ICMBio staff were joined on their trips to the community that had already been planned in their predetermined agenda. This minimised the risk of informant selection bias, and provided solid insight in the way that ICMBio approached the community. While staying in the reserve, there were numerous days in which community members were accompanied in their daily life activities, like the planting of manioc (Manihot esculenta), cooking and eating, without the involvement of ICMBio staff. In addition, ICMBio's staff's interaction with the community was studied. Interviews were conducted to gain a more in-depth knowledge of the interaction between ICMBio and the reserve (see sub research question 1 and 2). The interview questions were open-ended and formulated beforehand (in contrast to the informal conversations earlier mentioned) (Appendix A). Interviewees were given the opportunity to offer extensive answers, and were encouraged to elaborate on their answers most pertinent to our research questions [70]. Five women (one aged 30-40, all others aged 40-50) and six men (two aged 20-30, two aged 30-40 and two aged 40-50) comprised these sets of interviews. They were selected to ensure the geographical representation of small settlements within the reserve (Figure 1). Convenience sampling was used to find suitable respondents [69].

We also asked community members about hunting preferences (e.g., where they hunted and what species they hunted). This form of data collection helped to identify behaviours in the contexts of logic of practice and situated agency. These interviews were used to triangulate earlier observations in the field, and to compare the outcome with comments of other community members during informal conversations. Several expert interviews were conducted too [71]. The manager of the reserve was interviewed on various occasions, because of her expertise on communication with the inhabitants of the reserve. Various scientists operating in the area were interviewed, including one involved in a project on turtle and tortoise conservation in the reserve. Prior to every in-depth interview, the interviewees were informed about the goal of the interview, the confidentiality of information, that they were never obliged to answer, and that they could quit the interview at any time [72]. Community leaders, approached by ICMBio's reserve manager, gave their free, prior and informed consent for the execution of this research and the publication of outcomes [69]. A voice recorder was used to record interviews-all interviewees had given their consent to do so. 

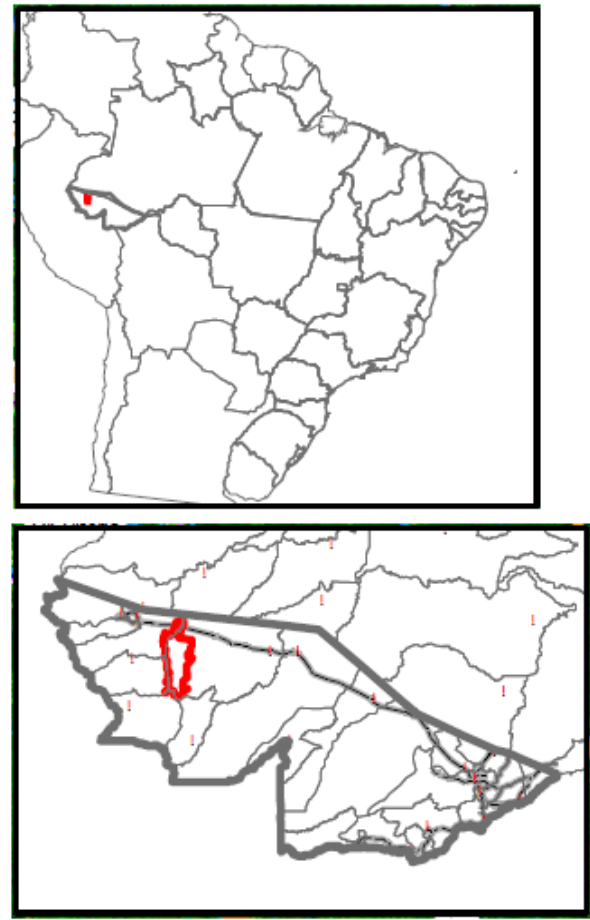

(a)

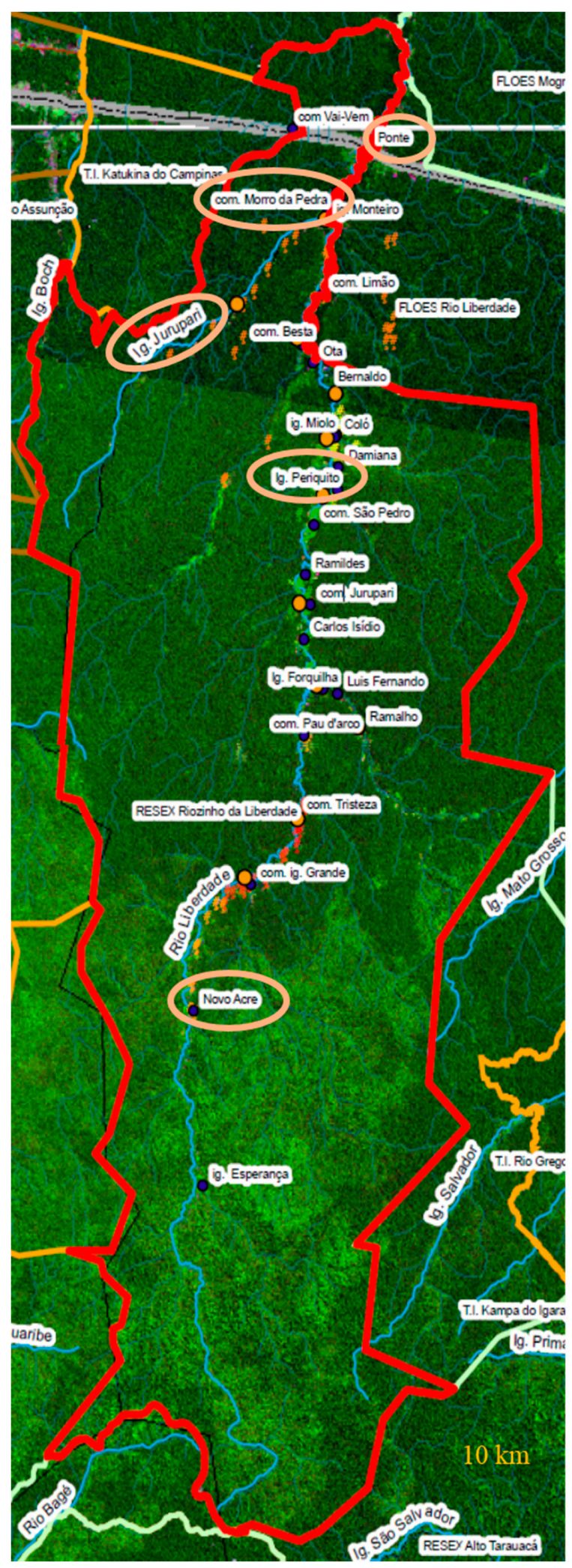

(b)

Figure 1. Overview of the reserve and its location in Brazil. Displayed are the biggest communities. The visited communities (Ponte da Liberdade, Morro da Pedra, Periquito, Passo da Pátria (here written as Novo Acre) and Jurupari) are circled. (a) Overview of the reserve and its location in Brazil; (b) Studied settlements are encircled. 
Every reserve created by ICMBio has a manager who makes decisions about the reserve, and who organises activities for and with community members. Time was spent with the manager of the Riozinho da Liberdade on a regular basis, mostly when visiting the reserve. Conversation topics included: the job as a manager; daily activities; and relationship with the community; as well as any other relevant topics that emerged in this context. It was made explicit that the relationship between the manager's organisation (ICMBio) and the community was studied, and the data was interpreted with that in mind. The manager of the Riozinho da Liberdade was therefore an extensive source of information. The community consists of 350 families that live in a complex local social-ecological system that has been shaped over many years. Our intention was not to conduct a comprehensive ethnographic study of this system, but rather to examine community-government interaction in relation to the conservation of biocultural diversity. For these purposes, our close interaction with community members and government staff was essential, and allowed us to triangulate insights.

\subsection{Data Analysis}

Data were analysed along the three sensitising concepts of the PBA framework. Arts et al. [17] describe how the best way to study logic of practice is to look at day-to-day decisions and the commonly accepted methods of carrying out activities. Habits in daily life regarding resource use, dietary habits regarding extractive products, and the way in which community members interact with ICMBio, were studied in order to identify logic of practice. The community has adapted to this specific area, with its specific climate, game availability, soil conditions and relation to ICMBio staff, for example. These and other elements provide the context for the community's situated agency. While adapting to this area together, social norms and values have adapted together too, creating 'situated' social cohesion within the community. Wagenaar [57] describes how 'situatedness', comparable to situated agency, can be studied by looking at the flexibility of people regarding their environment. Situated agency was studied by looking at how the community had adapted their extractive livelihoods to the area, by assessing the community's sense of connection with its environment, and by examining how the latter influenced their interaction with ICMBio. Thirdly, performativity might be visible through the way in which community members see and hear each other talk about the reserve. If an individual noticed that others never eat certain animals, he or she might take this into account while hunting. If people believed that certain species should not be consumed and they act upon this discourse, this would be an act of performativity. Moreover, it could be noticed how certain community members seem more influential than others and could possibly guide the behaviour of other community members. Here, performativity was studied by observing and identifying sayings that were acted upon (e.g., assumed truths), by listening to subjects of conversation that were often mentioned, and the way community members behaved towards ICMBio.

Raw data consisted of notes in the field diary, digital summaries of relevant events or conversations and interviews recorded with the voice recorder. Everything in the field diary was digitalised into Word and combined, in chronological order, with the texts following relevant events. All interviews were transcribed manually and analysed using QDA Miner Lite (version 2.0.5). Employing deductive coding linked to the three predefined sensitising concepts, the following labels were used: habits in daily-life activities (logic of practise), dietary habits (logic of practise), extractive behaviour (situated agency), performance of daily tasks adapted to the area (situated agency), adaptation to changes (situated agency), communication (performativity) and sense of connection within community (performativity). This was followed by another round of reading and inductive coding, from which the following categories emerged: approach, project information, practice, view of nature, response to ICMBio, consumed species, community approaching ICMBio, rules and regulations. We used inductive reasoning for our data analysis-data were collected, and a conclusion was drawn from this data [70]. The examples presented in the results section represent a cross-section of daily-life interactions between community, the government and the natural environment. 


\section{Results}

The community of the Riozinho da Liberdade viewed ICMBio as their government, regulator, judge and enforcer (a statement confirmed by the reserve manager). Community members went to the ICMBio office (in Cruzeiro do Sul, about $80 \mathrm{~km}$ from the entrance of the reserve) when they had questions, problems or conflicts. ICMBio was also approached when the community wanted to receive education on self-chosen subjects.

In this section, expectations towards ICMBio, ICMBio's approach towards the community, and the community's response towards ICMBio are presented (see sub-research questions 1-3). Several stories selected from our data will exemplify the practices detected.

\subsection{Community's Expectations}

The extent to which the community relies on the forest for resources was striking. Almost all resources needed to sustain livelihoods are found in surrounding forests, and community members regularly indicated the importance of their forest. Community members use the forest's wood for the construction of houses and boats (the most common method of transport within the reserve) and extract products from the forest for medicinal and dietary purposes. The forest is also the main source of protein for community members. This information was collected using participant observation, was brought up in interviews or informal conversations with community members, and was confirmed by the reserve's manager. Remarks such as "we need to protect the forest because we depend on it" and "the forest is important because it delivers our food" exemplify the extent to which the community is dependent on the forest, and the logic of practice that is implied: the forest makes up an important part of the community members' lifestyles without them thinking about it - for them the existence of the forest and their lifestyles are intertwined (logic of practice).

ICMBio is requested to financially support activities that benefit the common practices of the community, for example, to pay for oil or gasoline for chainsaws used for construction purposes. ICMBio has a monthly budget to spend on such activities. The institute aims to grant money for activities that benefit groups of people or sustainability. This illustrates not merely the dependency of the community on ICMBio, but also how logic of practice is a result of internal and external factors, the latter of which can only partially be influenced by the community.

Together, community members have adapted to the particular area that they live in. During the rubber boom, the tappers had lived hidden in the forests in the same region, where the rubber trees (Hevea brasiliensis) were found [59]. They were not allowed to grow their own vegetables or to breed their own cattle, earned little to no money and were forced to work exhausting hours. With the collapse of the rubber industry, the tappers settled together by the river Liberdade. As most rubber tappers had been small-scale farmers before switching to rubber tapping, they set up the same farming practices alongside the river. They fought for their rights to be acknowledged and protected from dangers such as (illegal) logging, poaching and (large-scale) cattle ranging. IBAMA acknowledged their rights and created the reserve, for which responsibility was handed over to ICMBio in 2007. Given this history it is not surprising that the community often reached out to ICMBio to support them in their livelihoods. This context was important for the community's situated agency because their expectations are adapted to this historically developed situation.

The subject of 'meat' was frequently brought up by community members (performativity)—which may be the result of years of living in poverty. The community's main food source, farinha, is available in plenty, but it does not contain much protein. The community viewed hunting as a common practice-for them, it was simply the process needed to feed the family. ICMBio was expected to respect these practices - it was mentioned that the community would not listen when the hunting of certain species would be prohibited, and that ICMBio would not be respected by community members if no meat was offered at a meeting. This was an example of performativity, because the general narrative that meat was important was tightly interwoven with hunting and livelihood practices. 


\subsection{ICMBio's Approach}

Apart from the rules created by the Brazilian government, ICMBio tried to enforce as few rules as possible on the community members, according to the manager. The reason for this was twofold. First, ICMBio wanted the community to be able to live their lives with as little outside interference as possible, and maintain a positive and equal relationship with the community. Second, ICMBio aimed to assist local communities that wanted to develop themselves. ICMBio organised, together with community members, projects aiming to help the community develop in a way that was deemed to be suitable for their environment. ICMBio wrote down the details of such projects, and calculated the input needed for projects to succeed. Projects were either based on economic development or education. Projects that did not directly affect community members, but the natural environment surrounding the settlements instead, were guided by ICMBio as well. The institute reminded the community about the financial opportunities the forest offers, such as the opportunity to make soap and oils from forest products. Meetings about this subject were attended by both men and women. ICMBio's presence was announced beforehand, and before every meeting, and all community members were told about the upcoming event. The institute facilitated the opportunity for the community to conduct such activities. ICMBio also handed out information about products that could be attractive for micro-economies, and about how to efficiently sell products to inhabitants of Cruzeiro do Sul (and other cities). Generally, ICMBio showed the community what could be possible, and how it could be of benefit to the community, but left the final decision to the community members. This indicates that ICMBio, in many cases, acted upon the logic of the practices of the community.

Logic of practice also shone through in the way ICMBio approached the community about the conservation of biodiversity. At the time of research, there was a project aimed at turtle and tortoise conservation. A researcher from Cruzeiro do Sul's University started this reptile conservation project in the reserve, in collaboration with ICMBio. According to this researcher, no exact numbers were known, but turtle and tortoise populations were in decline in the reserve. The project leader was aware of the difference in perception of nature from the community:

"Their sense of right and wrong is very subjective. For them is it natural to eat an animal. I asked a child of 5 years what she felt when she saw a picture of a fresh water turtle. She put her hand on her belly and went 'mmmm'."

The project initiators' main approach was to try and talk to community members about leaving resources for the future, and how animals have their own life, and are not only food. They tried to explain to community members that it was important not to eat all animals now, in order to save some for later. They engaged the community to discuss a different way of consumption, but in the end, left the responsibility to the community.

"We don't go there and put specific rules to the communities. They don't accept it. So every time we say, it's your house, it's your way, you decide what you want to do. If you want to protect one (beach), it's okay. Zero, okay, next year we will talk again."

Education about environmental awareness was prioritized by ICMBio. ICMBio staff regularly had meetings with community members about their lifestyle, what it meant to live in an extractive reserve, and how they could all work together for the benefit of the communities and its surroundings (situated agency). In line with environmental education, ICMBio organised educational meetings, in which the institute suggested to inhabitants of the community how to handle trash (situated agency and performativity). The community had a strong dislike against trash in the river, but with a growing degree of access to modern goods, the community faced a problem with waste disposal. It was, for example, advised not to throw trash in water bodies, but instead to assemble all trash in holes and cover them when full, or to take trash to the city or the closest road to be collected by the local trash department. The burning of trash was not advised because of the (toxic) emissions it produced. 


\subsection{Community's Response}

Overall, ICMBio employees were warmly welcomed by the community. The manager hugged the most important leaders of the community (even though a hand shake is the standard greeting in the state of Acre), and was invited for coffee in every settlement she visited. She did, however, mention how young people (aged 12-18) do not want to talk to her; they often walked away whenever she approached. The reason underlying this behaviour remained unknown, but there was suspicion of a general negative attitude towards ICMBio, passed on between teenagers (performativity).

Most community members gladly participated in meetings that were held by ICMBio to promote environmental awareness. According to the reserve's manager, reasons for participation varied amongst community members: it provided them an opportunity to talk to the government and they liked to participate in decision-making. Moreover, they might have been interested in learning new things, or they were curious about events happening. Inhabitants from the Riozinho da Liberdade generally responded positively to ICMBio's presence, but during mixed meetings, inhabitants from other extractive reserves (Reserva Extrativista Chico Mendes, Reserva Extrativista do Alto Tarauacá and Reserva Extrativista do Alto Juruá) were reported and observed to be less positive towards ICMBio. It was mentioned how those communities' experiences with ICMBio had been negative. The positive attitude from inhabitants of the Riozinho da Liberdade towards ICMBio could be interpreted in light of their situated agency; their specific history and their agency to deal with their history, and how the present challenges and opportunities had shaped the relationship between ICMBio and community members to how it appeared at the time of research.

Children participated enthusiastically in a meeting about the handling of trash, lining up to answer questions, and all listening carefully. However, the children were given candy wrapped in plastic as reward for their participation. Although they had listened to the talk about trash and trash collection carefully, candy wrappings could be found scattered across the floor after the lecture. Again, they continued their practices even though they had listened to someone telling them to collect their trash (logic of practice).

Adults participated actively in the same day's meeting too. Everybody looked at the distributed materials, and these were intensively discussed. According to the manager of the reserve, participants responded relatively enthusiastically to the suggestion of making oils out of forest products. She did wonder, however, if anyone would actually take up this kind of work. This stresses the point that ICMBio staff left community members to make their own decisions about their lifestyle: even though there were some doubts about the effect of the meetings, ICMBio continued to demonstrate to the community what (economic) development alternatives could be engaged with.

Community members' responses towards the turtle and tortoise conservation project varied. According to the main leader of the project, communities in general did not agree to conserve tortoises, because they liked tortoise meat too much. This contradicted other findings that there was some sustainability awareness amongst community members; for example, the leader of one settlement worried about other community members taking too many pigs when they were out hunting, not leaving enough numbers to reproduce. The response towards turtle conservation differed between community members. Some community members protected the eggs on their beaches or took them to a safe place to hatch. Other community members seemingly agreed with turtle conversation, but, as it turned out, continued eating turtle eggs. These examples show that logic of practice was sometimes differentiated within the community, but also that the community members' logic of practice was strong enough to make them continue their practices (either helping to preserve or not), even though the (long-term) benefits of conserving turtles and tortoises were demonstrated. In a similar way, hunting with dogs was still done illegally. ICMBio had prohibited hunting with dogs because some community members had complained about game scarcity as a result of this activity. Community members that suffered from this behaviour had asked ICMBio to solve this problem. This is telling, because community leaders could possibly have taken up this task themselves. Still ICMBio's ban had not been very successful. Although there were no exact numbers, the reserve's manager 
estimated that around $40-60 \%$ of the families still hunted with dogs, continuing with their logic of practice, despite internal and external conflicts. Our data showed that generally, the community knew about the rules that ICMBio prescribed them. For instance, they were aware they could not export bush meat and wood outside the reserve. Cases were cited of people reporting others who engaged in these prohibited activities. Many community members argued that enforcement capacity was insufficient, with only one ICMBio manager for all tasks. It was therefore plausible that illegal activities remained undetected by local staff.

\section{Discussion}

\subsection{Discussion of Results}

The objective of this study was to determine how community-government interaction on a practical level, may promote or hinder the conservation of biocultural diversity. A Practice-Based Approach was used to analyse our data. Seven types of interactions between ICMBio and the community of Riozinho da Liberdade were found (Table 1).

Table 1. Overview of the different types of interaction between ICMBio and the community of the Riozinho da Liberdade, with examples from the Results section.

\begin{tabular}{|c|c|}
\hline Interaction & Example \\
\hline Offering suggestions for the improvement of livelihoods & Organising meetings on more efficient farming strategies \\
\hline Offering alternative options for livelihoods & $\begin{array}{c}\text { Showing the possibilities and benefits of making soap out } \\
\text { of forest products }\end{array}$ \\
\hline Offering new ideas for consumptive behaviour & $\begin{array}{c}\text { Educating community members about the protection of } \\
\text { turtles and tortoises }\end{array}$ \\
\hline Creating new rules & Prohibiting hunting with dogs \\
\hline Enforcing existing rules & $\begin{array}{l}\text { Verifying that wood and bushmeat are not sold outside } \\
\text { the reserve }\end{array}$ \\
\hline Stimulating environmental awareness & Organising meetings about extractive lives \\
\hline Assisting community members with specific problems & Helping out with family quarrels \\
\hline
\end{tabular}

It is important to keep in mind here that ICMBio is a governmental organisation, and that the local and regional rules that the ICMBio office in Cruzeiro do Sul reproduces are to a large degree pre-set by the national department of ICMBio. This means that the rules regarding the conservation of biodiversity are not developed by Riozinho da Liberdade's local ICMBio management staff. Still, the local bricolage of general rules seemingly enhanced the conservation of biocultural diversity: e.g., no hunting with dogs helped to maintain and to reduce the destruction of the environment in which the community is located.

Another factor feeding into the conservation of biocultural diversity is that ICMBio takes local practices into account to make educational programmes more suitable for the inhabitants of the reserve. Older educational books showed pictures of elephants and giraffes-animals that children of the reserve had never seen. ICMBio has aspired to make educational programmes more fitting with the context in which they are growing up in. However, staff have conceded that this is an ambition for the long term.

The turtle and tortoise conservation project acted upon the habits of community members too. The manager of the project was aware of the fact that the eating of turtles and tortoises was a regular behaviour for community members (logic of practice). The manager stated that the prohibition of consumption of this protected species would likely be ineffective from a conservation point of view too, because of the difficulty of enforcement. Instead, the project manager tried to inform the community about the animals that they were consuming, and about the sustainable use of resources, hoping that they would adopt a different mindset. This was a clear act of influencing the logic of practice of the community. He also stressed that in the end, the community made the decision about participating in the project. It was debatable whether this approach promoted or hindered the conservation of 
biocultural diversity. On the one hand, if the project is successful, more turtles and tortoises would be available, which means that the community could continue consuming according to its preferences. On the other hand, the initiative to directly conserve these turtles was an external intervention that did not align with the community's own approach. If the turtle and tortoise conservation project does not interfere with the community's consumption patterns, the species could go extinct locally, potentially driving the community to switch to other wild animals. Questions surrounding the conservation of biocultural diversity were thus also questions about sustainability, cultural adaptation and change, and value-laden interventions related to biodiversity. Going from our findings, we argue that these questions are best answered locally by the stakeholders who are most involved in the day-to-day activities in the area, if they are collaboratively and deliberately (even if implicitly) negotiated.

Another example of ICMBio-community interaction revolved around the community's desire to intellectually develop themselves. ICMBio tries to stimulate the community to stay close to their cultural identity and practical ways of operating, which tends to be in line with conceived ideas of conserving biocultural diversity [20]. ICMBio gives lectures about what extractivism entails, to engage them to remain connected to the community. The institute also encourages community members to think about why they like living in the reserve-even though teenagers and young adults increasingly attend colleges and universities outside the reserve. It could be said though, that in line with the critiques of the representations of 'ecological indians' (cf. [34]), the need for traditional communities to stay close to their roots and to connect with their environment is an external notion. On the other hand, ICMBio acknowledges the desire of development and the way in which the community can change over time, thereby also acknowledging the community's agency and independence.

At the time of study, ICMBio was not fully capable of dealing with non-compliance issues. Although more employees could potentially help to control non-compliant behaviour, it has been observed that more enforcement does not necessarily lead to more compliance [58]. Moreover, even though non-compliant behaviour remains to some extent socially accepted within the community (such as the consumption of tortoise meat or hunting with dogs), the constructive interaction between community and government seems to benefit the protection of biocultural diversity on many other levels.

\subsection{Discussion of Theory, Methods and Scope for Further Study}

Using a PBA to focus on people's behaviours enabled us to detect non-compliant behaviour that might have gone unnoticed if a governmentality lens had been used. Moreover, if we had only looked at intentions and sayings, we would have quite possibly found that community members were aware of the prohibition of hunting with dogs, and would have agreed on conserving turtles and tortoises.

Nonetheless, 'governmentality' might have been a suitable framework for our data in some instances. For example, the notion that it would be best to conserve turtles and tortoises is an external idea that authorities, in this case scientists, seek to have internalised by locals. Contradicting, for example, Agrawal's [11] findings, not many community members did take up this idea, and they did not implement it in their lifestyle, even though the project has been running for 15 years. As another example, during meetings, children were often rewarded for their presence and engagement by ICMBio with candy and chocolate, and adults are offered meals if long meetings were planned. This emphasized ICMBio's role as a caretaker and the community as those who need to be taken care of-which is a picture that fits the governmentality framework. Indeed, the disruptive history of the area has fed into a paternalistic relationship between the community and government. Still, the importance of our PBA-structured results vis-a-vis the governmentality framework, is the emerging insight that a close connection between the government and local community does not equal compliance, but rather a complex assemblage of compliance and non-compliance expressions, nurtured by the community's own logic (Figure 2). 
Overview of how governmentality and PBA treat subjects' own logic

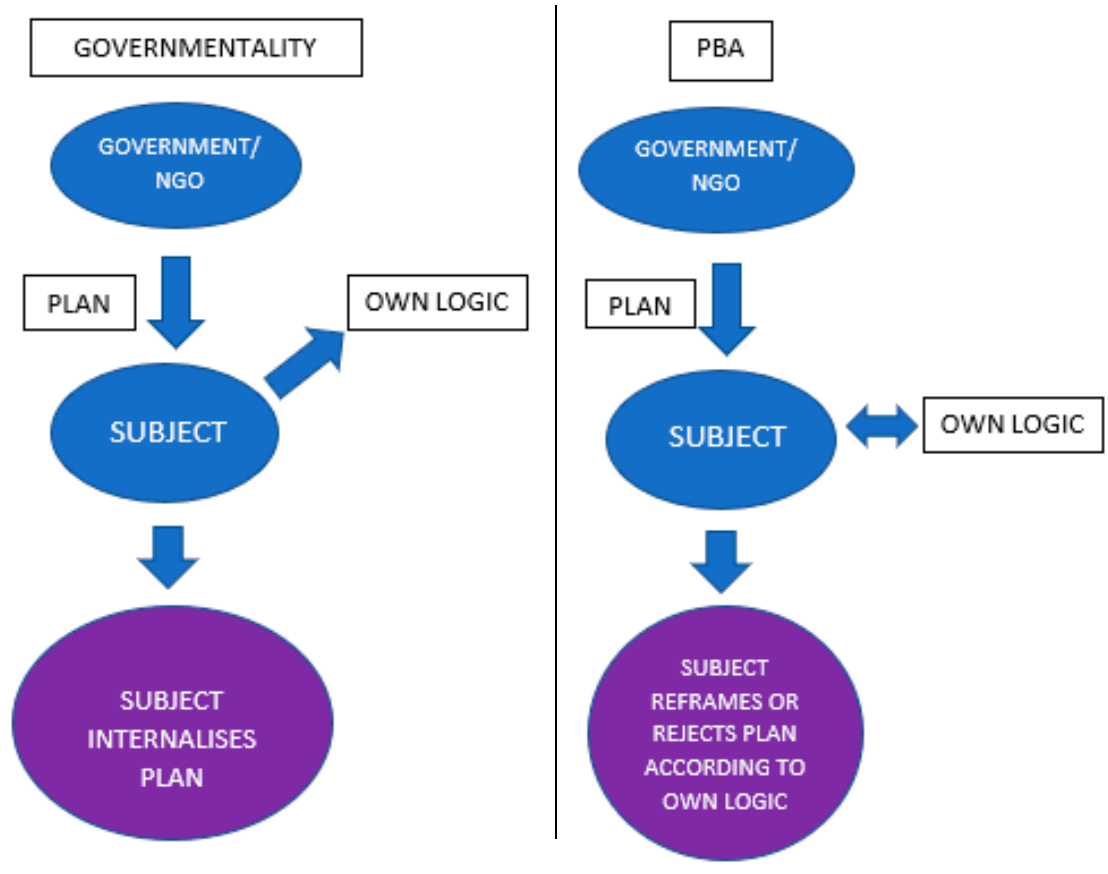

Figure 2. Governmentality states that subjects will internalise external plans and reject their own logic, while the Practice-Based Approach states that subjects mix external plans with their own logic and respond to outsiders' plans according to their own logic.

The combination of interviewing, participant observation and active participation has proven to provide valuable insight into the community's lifestyle [73]. Indeed, this combination of methods aligned with the Practice-Based Approach, and the combination of methods proved useful with regard to inter-subject data triangulation. Further study could analyse the approach of managers of other extractive reserves, to gain deeper insight into the exact role of managers' styles and approaches in relation to community-government interaction and (non-)compliance.

\section{Conclusions}

Our main research question was formulated as: How may community-government interactions on a practical level promote or hinder the conservation of biocultural diversity? Our findings show that a close interaction between community and government can promote the conservation of biocultural diversity. Seven types of government-community interactions were found: the offering of suggestions for the improvement of livelihoods, the offering of alternative options for livelihoods, the offering of new ideas for consumptive behaviour, the creation of new rules, the enforcement of existing rules, the stimulation of environmental awareness, and the assistance of community members with specific problems. These different interactions were related to the specific requirements of the community. This approach resulted in mutual understandings between the parties described, but this did not necessarily equal compliance. As is observed in literature, a problematic relationship between the government and the local community can hinder the conservation of biocultural diversity $[35,38,74]$. Our research shows that problematic relationships are not a given.

The Practice-Based Approach theory turned out to be suitable for analysing the daily practices in the context of community-government interaction. There is scope for further research building on this approach in relation to the topic of biocultural diversity, as the latter is often so tightly interwoven with the daily practices of many local communities around the world. Our work shows that while, from a government perspective, compliance may be suboptimal, biocultural diversity can still be reproduced through interactions between the community and the government, and thus be conserved. 
Author Contributions: Conceptualization, M.L.J.M. and K.A.; Methodology, M.L.J.M., S.D.M. and K.A.; Software, M.L.J.M.; Formal Analysis, M.L.J.M.; Investigation, M.L.J.M., S.D.M.; Writing and Original Draft Preparation, M.L.J.M. and K.A.; Writing-Review and Editing, M.L.J.M., S.D.M. and K.A.; Visualization, M.L.J.M.; Supervision, K.A.

Acknowledgments: We would like to kindly thank ICMBio's local staff for generously facilitating our investigation. All members of the Riozinho da Liberdade community too are warmly thanked for their hospitality, warmth and willingness to allow us to join in on their daily lives. This work has benefitted from constructive comments by two anynomyous reviewers-we appreciate their efforts very much.

Conflicts of Interest: The authors declare no conflict of interest.

\section{Appendix A}

Interview questions for community members

- Could you tell me about your daily life and your work?

- Where do you hunt?

- Where do you fish?

- What plants do you grow in your garden?

- What species of fish do you eat?

- What animals do you hunt?

- How many times a week do you fish?

- Are there any types of fish you do not eat?

- Are there animals that are not hunted?

- Are there people that do not use resources sustainably?

- Do all community members live the same lifestyle?

- Are there places where people do not fish?

- Do you eat animals that have their young with them?

Interview questions for experts

- Can you tell me about your project?

- Can you tell me about your experience in the community?

- Do you think the community has any idea about sustainability?

- Do community members consume all species they encounter?

- Does the community have plenty of space to hunt?

- Do community members engage in conversations about conservation?

- Do all settlements know about conservation efforts?

- Do people outside the reserve have the same consumption patterns regarding game?

- Are community teachers interested in awareness projects?

- Do you have any idea about the size of the turtle and tortoise population?

- How do you communicate with community members about turtle and tortois consumption?

- Do community members keep their promises regarding natural resource use?

Interview questios for ICMBio local staff

- Does the community have a sense of sustainability awareness?

- Does the community act upon sustainability beliefs?

- Do people close to the road have different eating habits than people far away from the road?

- Is the community aware of habitat degradation and/or species decline?

- How often do you visit the reserve?

- How often do community members visit you? 
- For what reasons do community members visit you?

- Are there problems in the reserve that you cannot solve?

- Do community members like visits from ICMBio?

- Do you have the same approach as managers of other reserves?

\section{References}

1. Gavin, M.C.; McCarter, J.; Mead, A.; Berkes, F.; Stepp, J.R.; Peterson, D.; Tang, R. Defining biocultural approaches to conservation. Trends Ecol. Evol. 2015, 30, 140-145. [CrossRef] [PubMed]

2. Berkes, F. Community-based conservation in a globalized world. Proc. Natl. Acad. Sci. USA 2007, 104, 15188-15193. [CrossRef]

3. Colding, J.; Folke, C.; Elmgvist, T. Social institutions in ecosystem management and biodiversity conservation. Trop. Ecol. 2003, 44, 25-41.

4. Western, D.; Wright, M. Natural Connections: Perspectives on Community-Based Conservation; Island Press: Washington, DC, USA, 1994.

5. Larson, L.R.; Conway, A.L.; Krafte, K.E.; Hernandez, S.M.; Carroll, J.P. Community-based conservation as a potential source of conflict around a protected area in Sierra Leone. Environ. Conserv. 2016, 43, 242-252. [CrossRef]

6. Hulme, D.; Murphree, M. Communities, wildlife and the "new conservation" in Africa. J. Int. Dev. 1999, 11, 277-285. [CrossRef]

7. Boafo, Y.A.; Saito, O.; Kato, S.; Kamiyama, C.; Takeuchi, K.; Nakahara, M. The role of traditional ecological knowledge in ecosystem services management: The case of four rural communities in Northern Ghana. Int. J. Biodivers. Sci. Ecosyst. Serv. Manag. 2016, 12, 24-38. [CrossRef]

8. Negi, C.S. Traditional culture and biodiversity conservation: Examples from Uttarakhand, Central Himalaya. Mt. Res. Dev. 2010, 30, 259-265. [CrossRef]

9. Aiken, S.R.; Leigh, C.H. Dams and indigenous peoples in Malaysia: Development, displacement and resettlement. Geogr. Ann. Ser. B Hum. Geogr. 2015, 97, 69-93. [CrossRef]

10. Dowie, M. Conservation Refugees: The Hundred-Year Conflict between Global Conservation and Native Peoples; MIT Press: London, UK, 2009; Volume 20, ISBN 978-0262012614.

11. Agrawal, A. Environmentality: Community, intimate government, and the making of environmental subjects in Kumaon, India. Curr. Anthropol. 2005, 46, 161-190. [CrossRef]

12. Cepek, M.L. Foucault in the forest: Questioning environmentality in Amazonia. Am. Ethnol. 2011, 38, 501-515. [CrossRef]

13. Gosling, A.; Shackleton, C.M.; Gambiza, J. Community-based natural resource use and management of Bigodi Wetland Sanctuary, Uganda, for livelihood benefits. Wetl. Ecol. Manag. 2017, 25, 717-730. [CrossRef]

14. Golden, A.S.; Naisilsisili, W.; Ligairi, I.; Drew, J.A. Combining natural history collections with fisher knowledge for community-based conservation in Fiji. PLoS ONE 2014, 9, e98036. [CrossRef] [PubMed]

15. Singh, N.M. The affective labor of growing forests and the becoming of environmental subjects: Rethinking environmentality in Odisha, India. Geoforum 2013, 47, 189-198. [CrossRef]

16. Mathez-Stiefel, S.; Boillat, S.; Rist, S. Promoting the diversity. In Endogenous Development and Bio-Cultural Diversity; COMPAS-CDE: Leusden, The Netherlands, 2007; pp. 67-81.

17. Arts, B.; Behagel, J.; van Bommel, S.; de Koning, J.; Turnhout, E. Forest and Nature Governance: A Practice-Based Approach; Springer: Dordrecht, The Netherlands, 2012.

18. Ayana, A.N.; Vandenabeele, N.; Arts, B. Performance of participatory forest management in Ethiopia: Institutional arrangement versus local practices. Crit. Policy Stud. 2017, 11, 19-38. [CrossRef]

19. Maffi, L. Linguistic, cultural, and biological diversity. Annu. Rev. Anthropol. 2005, 34, 599-617. [CrossRef]

20. Elands, B.H.M.; Vierikko, K.; Andersson, E.; Fischer, L.K.; Gonçalves, P.; Haase, D.; Kowarik, I.; Luz, A.C.; Niemelä, J.; Santos-Reis, M.; et al. Biocultural diversity: A novel concept to assess human-nature interrelations, nature conservation and stewardship in cities. Urban For. Urban Green. 2018. [CrossRef]

21. Wiersum, K.F. New Interest in Wild Forest Products in Europe as an Expression of Biocultural Dynamics. Hum. Ecol. 2017, 45, 787-794. [CrossRef] [PubMed]

22. Heckenberger, M. Biocultural diversity in the southern Amazon. Diversity 2009, 2, 1-16. [CrossRef] 
23. Hajer, M.; Laws, D. Ordering through discourse. In The Oxford Handbook of Public Policy; Oxford University Press: Oxford, UK, 2006; pp. 251-268.

24. Cocks, M. Biocultural diversity: Moving beyond the realm of "indigenous" and "local" people. Hum. Ecol. 2006, 34, 185-200. [CrossRef]

25. Ens, E.J.; Pert, P.; Clarke, P.A.; Budden, M.; Clubb, L.; Doran, B.; Douras, C.; Gaikwad, J.; Gott, B.; Leonard, S.; et al. Indigenous biocultural knowledge in ecosystem science and management: Review and insight from Australia. Biol. Conserv. 2015, 181, 133-149. [CrossRef]

26. Gavin, M.C.; McCarter, J.; Berkes, F.; Mead, A.T.P.; Sterling, E.J.; Tang, R.; Turner, N.J. Effective biodiversity conservation requires dynamic, pluralistic, partnership-based approaches. Sustainability 2018, 10, 1846. [CrossRef]

27. Cocks, M.L.; Wiersum, F. Reappraising the concept of biocultural diversity: A perspective from South Africa. Hum. Ecol. 2014, 42, 727-737. [CrossRef]

28. Wiley, A.S.; Cullin, J.M. What Do Anthropologists Mean When They Use the Term Biocultural? Am. Anthropol. 2016, 118, 554-569. [CrossRef]

29. Eser, U. Ethical perspectives on the preservation of biocultural diversity. Bodenkultur 2009, 60, 9-14.

30. Buizer, M.; Elands, B.; Vierikko, K. Governing cities reflexively-The biocultural diversity concept as an alternative to ecosystem services. Environ. Sci. Policy 2016, 62, 7-13. [CrossRef]

31. Watts, J. Jair Bolsonaro's rise to power casts shadow over UN environment conference: Participants at biodiversity convention say Amazon protections are under threat. Available online: https://www. theguardian.com/world/2018/nov/18/jair-bolsonaro-election-sparks-fears-for-brazil-biodiversity (accessed on 23 November 2018).

32. Arts, K.; Rabelo, M.; De Figueiredo, D.; Maffey, G.; Ioris, A.; Girard, P. Online and Offline Representations of Biocultural Diversity: A Political Ecology Perspective on Nature-Based Tourism and Indigenous Communities in the Brazilian Pantanal. Sustainability 2018, 10, 3643. [CrossRef]

33. Ojha, H.R.; Ford, R.; Keenan, R.J.; Race, D.; Carias Vega, D.; Baral, H.; Sapkota, P. Delocalizing Communities: Changing Forms of Community Engagement in Natural Resources Governance. World Dev. 2016, 87, $274-290$. [CrossRef]

34. Conklin, B.A.; Graham, L.R. The Shifting Middle Ground: Amazonian Indians and Eco-Politics. Am. Anthropol. 1995, 97, 695-710. [CrossRef]

35. Ribot, J.C.; Agrawal, A.; Larson, A.M. Recentralizing while decentralizing: How national governments reappropriate forest resources. World Dev. 2006, 34, 1864-1886. [CrossRef]

36. Ribot, J.C. Democratic decentralization of natural resources. In Beyond Structural Adjustment The Institutional Context of African Development; Springer: Berlin, Germay, 2003; pp. 159-182.

37. Agrawal, A.; Gibson, C.C. Enchantment and disenchantment: The role of community in natural resource conservation. World Dev. 1999, 27, 629-649. [CrossRef]

38. Brockington, D. Forests, community conservation, and local government performance: The village forest reserves of Tanzania. Soc. Nat. Resour. 2007, 20, 835-848. [CrossRef]

39. Zent, E.L.; Zent, S. On biocultural diversity from a Venezuelan perspective: Tracing the interrelationships among biodiversity, culture change and legal reforms. In Biodiversity and the Law; Routledge: Abingdon-on-Thames, UK, 2012; pp. 127-150.

40. Hay-Edie, T.; Howard, P.; Martin, G.; McCandless, S. The roles of local, national and international designations in conserving biocultural diversity on a landscape scale. Int. J. Herit. Stud. 2011, 17, 527-536. [CrossRef]

41. Apgar, J.M.; Ataria, J.M.; Allen, W.J. Managing beyond designations: Supporting endogenous processes for nurturing biocultural development. Int. J. Herit. Stud. 2011, 17, 555-570. [CrossRef]

42. Maffi, L.; Woodley, E. Biocultural Diversity Conservation: A Global Sourcebook; Routledge: Abingdon-on-Thames, UK, 2012; ISBN 1136544267.

43. Foucault, M. Governmentality; Harvester Wheatsheaf: London, UK, 1991.

44. Silva, L. Foucault in the landscape: Questioning governmentality in the Azores. Landsc. Res. 2015, 40, 397-410. [CrossRef]

45. Fletcher, R. Environmentality unbound: Multiple governmentalities in environmental politics. Geoforum 2017, 85, 311-315. [CrossRef] 
46. Haller, T.; Acciaioli, G.; Rist, S. Constitutionality: Conditions for crafting local ownership of institution-building processes. Soc. Nat. Resour. 2016, 29, 68-87. [CrossRef]

47. Haller, T.; Belsky, J.M.; Rist, S. The Constitutionality Approach: Conditions, Opportunities, and Challenges for Bottom-Up Institution Building. Hum. Ecol. 2018, 46, 1-2. [CrossRef]

48. Haller, T.; Merten, S. Crafting Our Own Rules: Constitutionality as a Bottom-Up Approach for the development of By-Laws in Zambia. Hum. Ecol. 2018, 46, 3-13. [CrossRef]

49. Brunner, R.D.; Clark, T.W. A Practice-based Approach to Ecosystem Management: Aproximación al Manejo de Ecosistemas Basada en la Práctica. Conserv. Biol. 1997, 11, 48-58. [CrossRef]

50. van der Arend, S.; Behagel, J. What participants do. A practice based approach to public participation in two policy fields. Crit. Policy Stud. 2011, 5, 169-186. [CrossRef]

51. Arts, B.; Behagel, J.; Turnhout, E.; de Koning, J.; van Bommel, S. A practice based approach to forest governance. For. Policy Econ. 2014, 49, 4-11. [CrossRef]

52. Behagel, J.H.; Arts, B.; Turnhout, E. Beyond argumentation: A practice-based approach to environmental policy. J. Environ. Policy Plan. 2017, 1-13. [CrossRef]

53. Bourdieu, P. The Logic of Practice; Polity Press: Cambridge, UK, 1990.

54. Behagel, J.; Arts, B.; van Bommel, S.; de Koning, J.; Turnhout, E. The Promise of Practice: The Value of the Practice Based Approach for Forest and Nature Governance Studies. In Forest and Nature Governance; Springer: Berlin, Germany, 2012; pp. 243-255.

55. Krott, M.; Giessen, L. Learning from practices-Implications of the "practice based approach" for forest and environmental policy research. For. Policy Econ. 2014, 49, 12-16. [CrossRef]

56. Stellmacher, T.; Mollinga, P. The institutional sphere of coffee forest management in Ethiopia: Local level findings from Koma forest, Kaffa zone. Int. J. Soc. For. 2009, 2, 43-66.

57. Wagenaar, H. “Knowing” the rules: Administrative work as practice. Public Adm. Rev. 2004, 64, 643-656. [CrossRef]

58. Bragagnolo, C.; Correia, R.; Malhado, A.C.M.; de Marins, M.; Ladle, R.J. Understanding non-compliance: Local people's perceptions of natural resource exploitation inside two national parks in northeast Brazil. J. Nat. Conserv. 2017, 40, 64-76. [CrossRef]

59. Vadjunec, J.M.; Gomes, C.V.A.; Ludewigs, T. Land-use/land-cover change among rubber tappers in the Chico Mendes Extractive Reserve, Acre, Brazil. J. Land Use Sci. 2009, 4, 249-274. [CrossRef]

60. Schmink, M.; Wood, C.H. Contested Frontiers in Amazonia, 1st ed.; Columbia University Press: New York, NY, USA, 1992.

61. Salisbury, D.S.; Schmink, M. Cows versus rubber: Changing livelihoods among Amazonian extractivists. Geoforum 2007, 38, 1233-1249. [CrossRef]

62. Diegues, C.A. Marine Protected Areas and Artisanal Fisheries in Brazil; International Collective in Support of Fishworkers: Chennai, India, 2008.

63. Criação de Unidades de Conservação. Available online: http://www.icmbio.gov.br/portal/ criacaodeunidadesdeconservacao (accessed on 12 September 2018).

64. Maciel, R.C.G.; da Silveira Cavalcanti, F.C.; de Souza, E.F.; de Oliveira, O.F.; Filho, P.G.C. The “Chico Mendes" extractive reserve and land governance in the Amazon: Some lessons from the two last decades. J. Environ. Manag. 2018, 223, 403-408. [CrossRef]

65. Athayde, S.; Stepp, J.R.; Ballester, W.C. Engaging indigenous and academic knowledge on bees in the Amazon: Implications for environmental management and transdisciplinary research. J. Ethnobiol. Ethnomed. 2016, 12, 26. [CrossRef]

66. Wartmann, F.M.; Purves, R.S. 'This is not the jungle, this is my barbecho': Semantics of ethnoecological landscape categories in the Bolivian Amazon. Landsc. Res. 2017, 43, 77-94. [CrossRef]

67. Kohn, E. Anthropology of ontologies. Annu. Rev. Anthropol. 2015, 44, 311-327. [CrossRef]

68. Evans, K.; de Jong, W.; Cronkleton, P.; Sheil, D.; Lynam, T.; Kusumanto, T.; Colfer, C.J.P. Guide to Participatory Tools for Forest Communities; CIFOR: Bogor, Indonesia, 2006.

69. Bernard, H.R. Research Methods in Anthropology, 5th ed.; AltaMira Press: Plymouth, UK, 2011.

70. Albuquerque, U.P.; Cruz da Cunha, L.V.F.; Lucena, R.F.P.; Alves, R.R.N. Methods and Techniques in Ethnobiology and Ethnoecology; Humana Press: New York, NY, UAS, 2014.

71. Bogner, A.; Littig, B.; Menz, W. Interviewing Experts (Research Methods Series); Palgrave Macmillan UK: Basingstoke, UK, 2009. 
72. Newing, H. Conducting Research in Conservation; Routledge: New York, NY, USA, 2011; Volume 1, ISBN 9788578110796.

73. Fairhead, J.; Leach, M. Misreading the African Landscape Society and Ecology in a Forest-Savanna Mosaic Part of African Studies; Cambridge University Press: Cambridge, UK, 1996.

74. Moreto, W.D.; Brunson, R.K.; Braga, A.A. 'Anything We Do, We Have to Include the Communities': Law Enforcement Rangers' Attitudes Towards and Experiences of Community-Ranger Relations in Wildlife Protected Areas in Uganda. Br. J. Criminol. 2017, 57, 924-944. [CrossRef]

(C) 2018 by the authors. Licensee MDPI, Basel, Switzerland. This article is an open access article distributed under the terms and conditions of the Creative Commons Attribution (CC BY) license (http:/ / creativecommons.org/licenses/by/4.0/). 